\title{
The effect of acquired microbial enzymes on assimilation efficiency in the common woodlouse, Tracheoniscus rathkei
}

Jerome J. Kukor and Michael M. Martin

Division of Biological Sciences, University of Michigan, Ann Arbor, MI 48109-1048, USA

Summary. The digestive tract of the common woodlouse, Tracheoniscus rathkei Brandt (Isopoda: Oniscoidea), contains digestive enzymes active against $\alpha$-1,4-glucans, which are the chief storage polysaccharides of vascular plants, algae, fungi, and animals, and $\beta$-1,3-glucans, which are present in algae and fungi. Digestive tract extracts also exhibit significant activity toward xylan and carboxymethylcellulose but negligible activity toward microcrystalline cellulose, substrates representative of the major structural polysaccharides of vascular plants. Low activity was detected toward pectin, and no activity was detected toward chitin. Activity toward xylan is due in part to microbial enzymes acquired from the leaf litter which was the isopod's normal food. Although ingested microbial xylanases are stable and active in the gut fluid, they do not make a quantitatively significant contribution to the isopod's ability to assimilate the hemicellulosic component of its diet. However, the assimilation of carbon from labeled plant fiber is enhanced in isopods which have acquired a cellulase by ingestion of leaf litter amended with a commercial preparation of the cellulase complex from the fungus, Penicillium funiculosum. This result demonstrates the potential contribution of acquired enzymes to the digestion of plant fiber in terrestrial detritivores. We urge caution, however, in assigning an important digestive function to ingested enzymes on the basis of evidence that only indicates that such enzymes are present in the gut fluid without additional evidence that their presence results in an enhancement of digestive efficiency.

Detritus (particulate organic matter and its associated microbial biomass) is generally considered to be a resource of low nutritive value owing to the high content of refractory polysaccharides and the considerable extent to which nutrients are complexed with lignins and other polyphenols (Swift et al. 1979). Microbial biomass is the most nutritious and digestible component of detritus, and numerous studies have demonstrated a preference on the part of detritivores for litter which supports a rich culture of microorganisms (Berrie 1976; Anderson and Sedell 1979; Cummins and Klug 1979). This preference for microbially colonized substrates has usually been interpreted as an ability of detriti-

Offprint requests to: M.M. Martin vores to select high quality over low quality food. Although the amount of microbial biomass is generally insufficient to make more than a minor contribution to the requirements for macronutrients of a detritus-feeding invertebrate (Baker and Bradnam 1976; Cummins and Klug 1979; Findlay et al. 1984; Martin and Kukor 1984), microbial tissue would be a rich source of micronutrients, minerals, and easily assimilated protein. However, another possible benefit that might accrue to a detritivore ingesting microbe-rich substrates is the acquisition of hydrolytic enzymes of microbial origin which are more effective than its own at degrading the refractory components of detrital food.

Secreted microbial hydrolytic enzymes are stable molecules that are distributed widely in detrital systems, either in solution or as parts of molecular complexes adsorbed onto particulate organic matter, humic substances, or clay colloids (Burns 1978; Linkins et al. 1978; Sinsabaugh et al. 1981). Ingested fungal enzymes play a crucial role in the digestion of wood in the alimentary tract of the fungusgrowing termite, Macrotermes natalensis (Martin and Martin 1978, 1979), the siricid woodwasp, Sirex cyaneus (Kukor and Martin 1983), and the cerambycid beetle, Monochamus marmorator (Kukor and Martin 1986). In this study we have assessed the possible contribution of ingested microbial enzymes to the digestion of detritus in the gut of the common woodlouse, Tracheoniscus rathkei. Earlier studies have indicated that woodlice are able to digest hemicellulose but not cellulose (Reyes and Tiedje 1976b), and that ingested microbial enzymes (Hassall and Jennings 1975) and bacteria (Reyes and Tiedje 1976a, b) may be present and active in the gut fluids.

\section{Methods and materials}

\section{Collection and maintenance of animals}

$T$. rathkei, a common isopod in northern deciduous forests, was collected from woodlots around Ann Arbor and was maintained in loosely covered glass jars in a darkened incubator at $26^{\circ} \mathrm{C}$. The bottom of each jar contained a $2 \mathrm{~cm}$ bed of water-soaked vermiculite, which provided moisture for the animals. The isopods were fed leaf litter taken from the collection sites. In experiments that involved animals reared on an artificial diet, isopods in groups of 100 were kept for 4-8 weeks on autoclaved pellets of Purina rabbit chow. 


\section{Extract preparation and enzyme assays}

The digestive tract, excluding the hepatopancreas, was removed by securing the animal with forceps and pulling posteriorly on the terminal body segments with another forceps. Since the $\mathrm{pH}$ of the digestive tract fluid ranged between 6.5 and 7.1 , extracts were prepared in $50 \mathrm{~m} M$ BISTRIS-PROPANE buffer (1,3-bis[tris(hydroxymethyl)methylamino]propane) (Sigma), $\mathrm{pH}$ 6.8. Digestive tracts were homogenized in a chilled glass mortar in BIS-TRISPROPANE buffer (extraction buffer) containing $20 \mathrm{mM}$ sodium tetraborate, $25 \mathrm{~m} M$ sodium ascorbate, $5 \mathrm{mM}$ sodium metabisulfite, and $5 \mathrm{~m} M$ diethyldithiocarbamate. Insoluble polyvinylpolypyrrolidone (PVP) was added to the extract to a final concentration of $5 \%$ (weight/volume) and the slurry was stirred for $1 \mathrm{hr}$ at $4^{\circ} \mathrm{C}$ under nitrogen. The addition of borate, ascorbate, metabisulfite, diethyldithiocarbamate, and PVP to the extraction buffer was necessary to prevent rapid browning of the extract and loss of enzymatic activity (Kelley and Adams 1977). Following centrifugation $\left(10,000 \times \mathrm{g}, 30 \mathrm{~min}, 4^{\circ} \mathrm{C}\right)$, the supernatant solution was filtered through a $0.2 \mu \mathrm{m}$ membrane and was stored at $-70^{\circ} \mathrm{C}$. For enzyme assays, extracts were made of the pooled digestive tracts from 10-50 isopods. For purification of the xylanases from $T$. rathkei, the digestive tracts from 400 animals were pooled.

The leaf litter extract was prepared by grinding $1 \mathrm{~kg}$ (wet weight) of frozen leaves with alumina in a chilled mortar, with the gradual addition of liquid nitrogen. The pulverized leaves were added to 2 liters of BIS-TRIS-PROPANE extraction buffer containing 5\% PVP, and the slurry was stirred at $4^{\circ} \mathrm{C}$ for $18 \mathrm{hrs}$. This extraction procedure, modified from Kelley and Adams (1977), was effective in reducing loss of enzymatic activity by reaction with phenolics in the leaves. Insoluble materials were removed by filtration through cheesecloth followed by centrifugation $\left(10,000 \times \mathrm{g}, 4^{\circ} \mathrm{C}, 30 \mathrm{~min}\right)$. The supernatant fluid was concentrated tenfold in a Pellicon cassette (PTGC membrane, Millipore), sterilized by filtration through a $0.2 \mu \mathrm{m}$ membrane, and stored at $-70^{\circ} \mathrm{C}$.

Activities toward larchwood xylan (United States Biochemical), carboxymethylcellulose (CMC) (Sigma), microcrystalline cellulose (Polysciences), citrus pectin (Sigma), potato amylose (Calbiochem), and laminarin (United States Biochemical) were assayed by measuring the rate of liberation of reducing groups (maltose equivalents), using the 3,5-dinitrosalicylic acid reagent (Bernfeld 1955) as adapted by Martin et al. $(1980,1981)$.

\section{Enzyme purification and analysis}

Xylanases from leaf litter and $T$. rathkei digestive tracts were purified by a combination of ion exchange chromatography, chromatofocusing, and gel filtration chromatography.

For anion exchange chromatography, the leaf litter or isopod extract was applied to a column $(2.6 \times 15 \mathrm{~cm})$ of DEAE-Sepharose CL6B (Pharmacia) equilibrated with $50 \mathrm{~m} M$ BIS-TRIS-PROPANE buffer, $\mathrm{pH}$ 6.8. Unbound proteins were eluted with $100 \mathrm{ml}$ of BIS-TRIS-PROPANE buffer, and bound proteins were eluted (in $10 \mathrm{ml}$ fractions) with a $0-1.5 \mathrm{M}$ linear $\mathrm{NaCl}$ gradient in $300 \mathrm{ml}$ of BISTRIS-PROPANE buffer. Protein concentration was monitored by absorbance at $280 \mathrm{~nm}$.
For chromatofocusing, the xylanase fractions which were eluted from the anion exchange column by $0.6-0.7 \mathrm{M}$ $\mathrm{NaCl}$ were combined, concentrated, and dialyzed against Polybuffer 74 (Pharmacia), $\mathrm{pH} 4.0$, and applied to a column $(1 \times 35 \mathrm{~cm})$ of PBE 94 (Pharmacia) equilibrated with $25 \mathrm{~m} M$ imidazole-HCl buffer, $\mathrm{pH}$ 7.4. Proteins with $\mathrm{pI}$ values between $\mathrm{pH} 7$ and 4 were eluted (in $5 \mathrm{ml}$ fractions) with $400 \mathrm{ml}$ of Polybuffer $74(0.0094 \mathrm{mM}$ per $\mathrm{pH}$ unit per $\mathrm{ml}$ ). Proteins with $\mathrm{pI}$ values below $\mathrm{pH} 4$ were eluted with $50 \mathrm{ml}$ of $1 \mathrm{M} \mathrm{NaCl}$ in Polybuffer 74, $\mathrm{pH} \mathrm{4.0.}$

The low pI xylanase fractions (pI less than $\mathrm{pH} 4$ ) obtained by chromatofocusing were further purified by gel filtration chromatography on a Varian TSK-G3000SW column $(7.5 \times 300 \mathrm{~mm})$ attached to a DuPont HPLC system. The column was equilibrated, and proteins were eluted with $50 \mathrm{~m} M$ BIS-TRIS-PROPANE buffer, pH 6.8, containing $10 \mathrm{~m} M \mathrm{NaCl}$.

Discontinuous-SDS-gradient gel electrophoresis was performed on $7.5-15 \%$ polyacrylamide gels using the system of Neville, as modified by Piccioni et al. (1982). Gels were stained with Brilliant Blue R250 (Sigma). Analytical isoelectric focusing was performed on ultrathin polyacrylamide gels (Servalyt Precotes, Serva Fine Biochemicals), as previously described (Kukor and Martin 1983).

\section{Assimilation efficiency on natural leaf litter}

Isopods in groups of 30 , randomized for size and sex, were placed on a $2.5 \mathrm{~mm}$ mesh polyethylene screen in a covered polyethylene container. The screen supported the animals and their food, but allowed fecal pellets to fall into the lower compartment of the container. The animals were provided daily with $2-3$ grams (fresh weight) of autoclaved, de-veined leaf litter fragments. Uneaten food and fecal pellets were also removed daily. A moistened sponge, attached to the inside of the container lid, provided moisture. The containers were kept in a darkened incubator at $26^{\circ} \mathrm{C}$. Each experiment lasted 7 days and was replicated 6 times. Approximate digestibility (or assimilation efficiency) was calculated on a dry weight basis from the expression, AD $(\%)=100$ (food ingested - feces)/food ingested. Assimilation efficiency measurements were made with two groups of isopods: (1) those reared for 4 weeks on normal leaf litter, and (2) those reared for 2 weeks on rabbit chow followed by 2 weeks on autoclaved leaf litter.

\section{Culturing isopods on a diet of leaf litter to which fungal cellulase had been added}

Disks $(1.5 \mathrm{~cm}$ diam) were cut from dead autoclaved black walnut (Juglans nigra) leaf litter, collected from the ground in October. The disks were soaked for $24 \mathrm{hr}$ at $4^{\circ} \mathrm{C}$ in $250 \mathrm{ml}$ of a solution of Penicillium funiculosum cellulase (Sigma) (20 units $/ \mathrm{ml}$ ). A second group of leaf disks was soaked in a solution of heat-inactivated (autoclaved) cellulase. Specific activity of adsorbed cellulase was determined by extracting weighed portions of leaf disks with BIS-TRISPROPANE buffer and assaying the extract for activity toward microcrystalline cellulose. Groups of 20 isopods were cultured for 2 weeks on each of the leaf disk preparations. Fecal pellets were removed and fresh leaf disks were provided daily. At the end of 2 weeks, 10 animals from each group were sacrificed and their gut fluids were assayed for cellulase activity. 
Assimilation efficiency on dual-labeled leaf litter by animals reared on a cellulase-amended diet

Dual-labeled leaf litter was prepared by incubating $4 \mathrm{gms}$ (dry weight) of leaf disks cut from autoclaved, dead black walnut leaves at $15^{\circ} \mathrm{C}$ for $18 \mathrm{hr}$ in $250 \mathrm{ml}$ of a solution of ${ }^{51} \mathrm{CrCl}_{3}$ (ICN) $\left(7.8 \times 10^{4} \mathrm{kBq}\right)$ in $0.01 N \mathrm{HCl}$. The disks were rinsed 3 times in water to remove excess $\mathrm{CrCl}_{3}$ and were then immersed in $20 \mathrm{ml}$ of a warm agar solution containing $1 \mathrm{gm}$ of pulverized $\left[\mathrm{U}_{-}{ }^{14} \mathrm{C}\right]$ wheat straw $\left(0.67 \times 10^{4}\right.$ $\mathrm{kBq} / \mathrm{gm}$ ) (Reyes and Tiedje 1976b). The specific activity of the dual-labeled disks was determined from individually weighed portions of dried, pulverized leaves, which were added to 3.5\% Cab-o-sil (Cabot Corp.) in ACS scintillation cocktail (Amersham) and counted by liquid scintillation spectrometry (Herscowitz and McKillip 1974), using channel $1(0-300)$ to count ${ }^{51} \mathrm{Cr}$ and channel $2(300-670)$ to count ${ }^{14} \mathrm{C}$. Efficiency determinations $\left(10-15 \%\right.$ for ${ }^{51} \mathrm{Cr}$ and $70-75 \%$ for ${ }^{14} \mathrm{C}$ ) and quench corrections were made by the H-number method of external standardization. Ten isopods that had been cultured for 2 weeks on black walnut leaf litter which had been amended with fungal cellulase were placed in an airtight $125 \mathrm{ml}$ flask containing the dual labeled black walnut leaf litter disks. The control flask contained 10 isopods that had been cultured for 2 weeks on black walnut leaf litter which had been amended with heat inactivated fungal cellulase. While the isopods were feeding on the dual-labeled leaf litter disks, the flasks were periodically flushed with air, and the ${ }^{14} \mathrm{CO}_{2}$ (along with other volatiles) in the exit gas was trapped in phenethylaminemethanol $(1: 1, \mathrm{vol} / \mathrm{vol})$ in ACS for scintillation counting. After 3 days of feeding on the dual-labeled leaf disks, the isopods were transferred to unlabeled leaf disks for an additional 24 hour so that residual labeled material in the gut might be voided and collected. At the end of the experiment, all fecal pellets and uneaten labeled leaf disks were separately dried and pulverized. Weighed portions were added to a Cab-o-sil-ACS cocktail for scintillation counting. ${ }^{51} \mathrm{Cr}:{ }^{14} \mathrm{C}$ ratios were calculated for leaf disks and fecal pellets, and assimilation efficiency was determined by the procedure of Calow and Fletcher (1972). At the end of the experiment, the digestive tracts of the isopods were homogenized in BIS-TRIS-PROPANE buffer and assayed for activity against microcrystalline cellulose.

\section{Results}

\section{Isopod and leaf litter carbohydrases}

The digestive tract of $T$. rathkei contains enzymes active against a variety of substrates representative of major classes of polysaccharides that occur naturally in vascular plants, algae, fungi and animals (Table 1). $\alpha$-Amylose (an $\alpha-1,4$-glucan) is the substrate toward which highest activity was observed. Although $\alpha-1,4$-glucans are a minor constituent of dead tissues derived from vascular plants, they are a major class of storage polysaccharide in fungi, animals, and live vascular plant tissue. Thus, to the extent that fungal tissue, invertebrate prey and foliage are included in the diet, digestive $\alpha-1,4-$ glucanases are of adaptive value to $T$. rathkei.

Considerable enzymatic activity was detected toward xylan and carboxymethylcellulose (CMC). Activity toward these two substrates is slightly lower $(P<0.05)$ in isopods maintained in the laboratory for four weeks on leaf litter than in individuals collected directly from natural populations. Activity toward larchwood xylan indicates the presence of enzymes required to degrade arabino-4-O-methylglucuronoxylans, which are a major class of hemicelluloses present in vascular plants. Activity toward carboxymethylcellulose indicates the presence of endoglucanases $\left(\mathrm{C}_{\mathrm{x}}\right.$-cellulases) which attack soluble degradation products of cellulose or amorphous regions of the predominantly crystalline structure of native cellulose. Activity toward carboxymethylcellulose is not necessarily indicative of an ability to digest cellulose, however, since the degradation of native cellulose requires the synergistic action of a complex of enzymes (Ljungdahl and Erikkson 1985). Indeed, enzymatic activity toward microcrystalline cellulose was barely detectable in the digestive tract fluid of $T$. rathkei, indicating that these animals do not possess a complete cellulase complex. These results are compatible with the conclusions of Reyes and Tiedje (1976b) that $T$. rathkei is able to digest hemicellulose but not cellulose.

Extracts of $T$. rathkei digestive tracts also possess low enzymatic activity toward citrus pectin, a methyl esterified galacturonan found in plant tissues, and laminarin, a $\beta-1,3-$ glucan present in algae and fungi. No activity was detected toward chitin, a major structural polymer found in fungal cell walls and arthropod cuticle.

In summary, the digestive capabilities of $T$. rathkei are similar to those reported for other terrestrial detritivores with omnivorous feeding habits (Nielsen 1962, 1963; Swift et al. 1979; Taylor 1982), including related species of terrestrial isopods (Paris 1963; Hartenstein 1964; White 1968; Edney et al. 1974; Shachak et al. 1976).

Since the leaf litter on which isopods feed is rich in decomposer microorganisms, it is possible that some of the enzymatic activity toward plant cell wall polysaccharides observed in the digestive tract of $T$. rathkei might be due to ingested microbial enzymes. Indeed, the leaf litter from which $T$. rathkei was collected in this study was found to have high levels of xylanase activity (Table 1). Isopods kept for four weeks on a microbe-free, enzyme-free diet of rabbit chow have a level of xylanase activity significantly lower $(P<0.05)$ than in either isopods collected from natural populations or ones cultured for four weeks on leaf litter in the laboratory (Table 1). When isopods maintained on rabbit chow were transferred from the artificial diet to autoclaved leaf litter, xylanase activity remained at reduced levels, demonstrating that the secretion of additional enzymes with activity toward xylan is not induced by heat-stable components of normal litter. These observations are compatible with the suggestion that isopods might acquire enzymes by ingestion, but they are by no means compelling evidence in favor of such a proposal.

\section{Purification and comparison of isopod and leaf litter xylanases}

When subjected to anion exchange chromatography, $14 \%$ ( 75 out of 520 units) of the total activity toward xylan in the gut fluid of $T$, rathkei reared on natural leaf litter eluted at $0.67 M \mathrm{NaCl}$ in a broad protein peak (Table 2). This protein peak and the enzyme activity it contained were completely absent from the gut fluid extract from isopods reared sequentially on a rabbit chow diet and then on autoclaved leaf litter. Enzymes present in this fraction are, therefore, 
Table 1. Enzymatic activity of extracts of Tracheoniscus rathkei digestive tracts and leaf litter toward various polysaccharides. The $\mathrm{pH}$ of the gut fluid ranged between 6.5 and 7.1

\begin{tabular}{|c|c|c|c|c|c|c|}
\hline Source of Extract & \multicolumn{6}{|c|}{ Enzymatic activity [units per milligram (dry weight) of dissolved solids in extract] ${ }^{a}$} \\
\hline \multicolumn{7}{|l|}{ T. rathkei } \\
\hline $\begin{array}{l}\text { Collected from natural } \\
\text { leaf litter }\end{array}$ & $\begin{array}{l}21.1 \pm 3.4 \\
(8)\end{array}$ & $\begin{array}{l}15.7 \pm 1.7 * \\
(7)\end{array}$ & $\begin{array}{l}7.7 \pm 1.0 \mathrm{~d}^{*} \\
(7)\end{array}$ & $\begin{array}{l}0.04 \pm 0.02 \\
(7)\end{array}$ & $\begin{array}{l}2.0 \pm 0.6 \\
(8)\end{array}$ & $\frac{1.7 \pm 0.3}{(8)}$ \\
\hline $\begin{array}{l}\text { Cultured for } 4 \text { weeks on } \\
\text { rabbit chow }\end{array}$ & ND & $\begin{array}{l}7.7 \pm 0.5 \mathrm{c} \\
(7)\end{array}$ & $\begin{array}{l}2.0 \pm 0.3 \text { ef } \\
(7)\end{array}$ & ND & ND & ND \\
\hline $\begin{array}{l}\text { Cultured for } 2 \text { weeks on rabbit } \\
\text { chow then for } 2 \text { weeks on } \\
\text { autoclaved leaf litter }\end{array}$ & ND & $\begin{array}{l}8.2 \pm 0.6 \mathrm{c} \\
(7)\end{array}$ & $\begin{array}{l}1.6 \pm 0.3 \mathrm{f} \\
(7)\end{array}$ & ND & ND & ND \\
\hline
\end{tabular}

Table 2. Summary of the xylanase purification sequences for extracts of natural leaf litter and digestive tracts of Tracheoniscus rathkei. Each value is the number of units of enzymatic activity (as defined in Table 1) contained in the fraction

\begin{tabular}{|c|c|c|c|}
\hline Fraction & $\begin{array}{l}\text { T. rathkei } \\
\text { from leaf } \\
\text { litter }\end{array}$ & $\begin{array}{l}\text { T. rathkei } \\
\text { from rabbit } \\
\text { chow and } \\
\text { autoclaved } \\
\text { leaf litter }\end{array}$ & $\begin{array}{l}\text { Leaf } \\
\text { litter }\end{array}$ \\
\hline Crude extract & 520 & 590 & 300 \\
\hline $\begin{array}{l}\text { Elution from ion exchange } \\
\text { column by } \mathrm{NaCl} \text { up to } \\
0.6 M\end{array}$ & 310 & 470 & 20 \\
\hline $\begin{array}{l}\text { Elution from ion exchange } \\
\text { column by } 0.6-0.7 \mathrm{M} \mathrm{NaCl}\end{array}$ & 75 & 0 & 250 \\
\hline $\begin{array}{l}\text { Elution from chromato- } \\
\text { focusing column between } \\
\text { pH } 7 \text { and pH } 4\end{array}$ & 30 & $\mathrm{ND}^{\mathrm{a}}$ & 60 \\
\hline $\begin{array}{l}\text { Elution from chromato- } \\
\text { focusing column } \\
\text { by } 1 \mathrm{M} \mathrm{NaCl}\end{array}$ & 40 & ND & 170 \\
\hline
\end{tabular}

candidates for acquired microbial enzymes derived from the leaf litter. In support of this possibility, we observed that when a leaf litter extract was subjected to a similar separation sequence, a large protein peak eluted between 0.6 and $0.7 \mathrm{M} \mathrm{NaCl}$ which contained $83 \%$ (250 out of 300 units) of the total xylanase activity of the original extract.

When the xylanase fractions from $T$. rathkei and leaf litter eluting between 0.6 and $0.7 M \mathrm{NaCl}$ from the ion exchange column were further fractionated on a preparative chromatofocusing column, only $40 \%$ (30 out of 75 units) and $24 \%$ ( 60 out of 250 units) of the xylanase activity from the isopods and the leaf litter, respectively, were eluted in the $\mathrm{pH}$ range between $\mathrm{pH} 7$ and $\mathrm{pH}$ 4. Most of the xylanase activity (40 out of 75 units in the $T$. rathkei preparation and 170 out of 250 units in the leaf litter preparation) re-

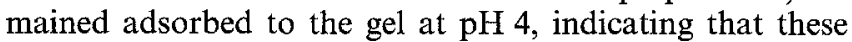
proteins have $\mathrm{pI}$ values less than $\mathrm{pH} 4$. These low-pI xylanases were eluted from the chromatofocusing column with a $1 M \mathrm{NaCl}$ solution. The xylanase activity present in this low pI fraction constituted $8 \%$ (40 out of 520 units) of the total xylanase activity in the original extract derived from $T$. rathkei.

The low-pI xylanases from the isopods and the leaf litter were subjected to HPLC gel permeation chormatography as a final purification step. In both preparations, the xylanase emerged from the column in comparable fractions as a single, symmetrical protein peak.

A comparison of the low-pI xylanase fraction from the isopod and leaf litter preparations was made by isoelectric focusing and discontinuous, denaturing-gel electrophoresis. In an analytical isoelectric focusing gel (nominal $\mathrm{pH}$ range of 3-6), the leaf litter and isopod xylanase fractions focused as a single band at the anodic end of the gel (Fig. 1). Unfortunately, the proximity to the anode prevented an accurate determination of pI. On an SDS-gradient gel, the low-pI xylanase fractions from leaf litter and $T$. rathkei digestive tract showed identical patterns (Fig. 2), with a major protein band having an estimated molecular mass of 72.8 kilodaltons.

These comparisons of leaf litter and isopod enzymes show that at least one xylanase present in the digestive fluids of $T$. rathkei reared on natural leaf litter is identical to a xylanase found in the leaf litter on which the isopods feed. This enzyme is absent from the digestive fluids of 


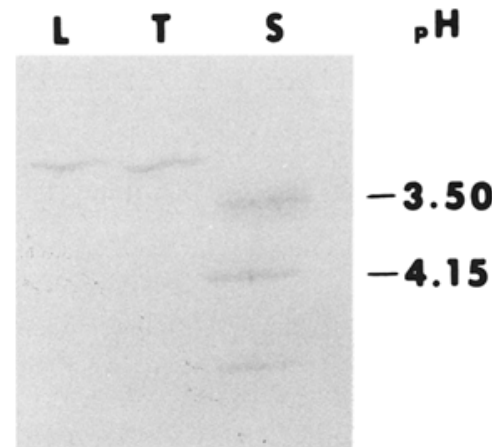

Fig. 1. Isofocusing gel of the low-pI xylanase from leaf litter $L$ and Tracheoniscus rathkei $T$. The nominal $\mathrm{pH}$ range of the gel is 3-6. The pI marker standards $S$ are amyloglucosidase $(\mathrm{pI}=3.50)$ and glucose oxidase $(\mathrm{pI}=4.15)$

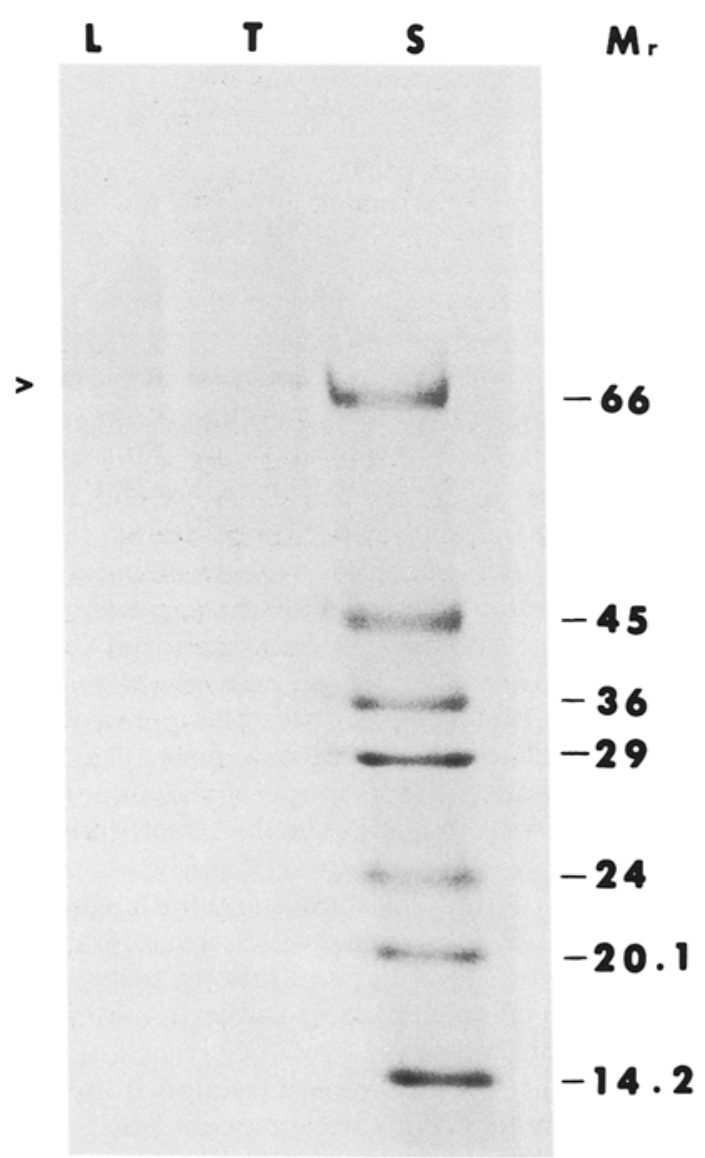

Fig. 2. SDS-gradient gel of the low-pI xylanase from leaf litter $L$ and Tracheoniscus rathkei $T$, and of selected molecular weight standards $S$. The apparent molecular mass of the major band (indicated by the carat) is 72.8 kilodaltons

isopods reared on sterile rabbit chow and autoclaved leaf litter. These results demonstrate that the isopods can acquire digestive enzymes by the ingestion of microbial enzymes present in their food.

It is also clear from the data in Tables 1 and 2, however, that most of the xylanase activity in the gut fluid of $T$. rathkei is not due to enzymes acquired from the detrital food. Animals maintained for a month on a diet that does
Table 3. Approximate digestibility of autoclaved leaf litter by Tracheoniscus rathkei

\begin{tabular}{ll}
\hline $\begin{array}{l}\text { Diet immediately prior } \\
\text { to experiment }\end{array}$ & $\begin{array}{l}\text { Approximate digestibility } \\
(\%)^{* a}\end{array}$ \\
\hline Four weeks on natural leaf litter & $\begin{array}{l}30.7 \pm 1.2 \\
(6)\end{array}$ \\
$\begin{array}{l}\text { Two weeks on rabbit chow } \\
\text { followed by two weeks on }\end{array}$ & $(6) .0 \pm 2.9$ \\
autoclaved leaf litter & \\
\hline
\end{tabular}

* Each value is the mean \pm standard error of the mean for the number of replicates in parenthesis. Differences between means are significant, $P<0.05$, T-test

a Duration of experiment was one week

not contain active microbial enzymes still have high levels of xylanase activity in their gut fluids. Furthermore, most of the xylanase activity in the isopods' gut fluid (310 out of 520 units or 470 out of 590 units) elutes from the anion exchange column in a fraction which contains only a small portion of the activity extracted from leaf litter ( 20 out of 300 units).

\section{Assimilation efficiency on natural leaf litter}

In order to assess the importance of the acquired microbial xylanase to $T$. rathkei, we compared the efficiencies of assimilation of autoclaved leaf litter by animals reared on natural leaf litter containing microbial xylanase and animals reared on an enzyme-free diet of rabbit chow and autoclaved litter. Animals reared on natural leaf litter digested approximately $30 \%$ of the dry matter in their food, while animals cultured on an enzyme-free diet digested 39\% (Table 3). This result shows that the acquisition of microbial xylanases by the isopods does not make them more efficient at digesting their natural food. Apparently the ingested microbial xylanases are redundant to the xylanases already present in the gut fluid, and consequently do not add to the animals' ability to digest the hemicellulosic component of fiber.

\section{Assimilation efficiency on dual-labeled leaf litter by animals reared on a cellulase-amended diet}

Since the isopods used in this study lacked the full complement of enzymes that make up the cellulase complex, it seemed possible that the ingestion of microbial cellulases might enhance their capacity to digest their natural food. Therefore, we assessed the effect of ingesting a food that contained microbial cellulases on the efficiency with which the animals assimilated plant fiber.

When a group of T. rathkei was allowed to feed for two weeks on black walnut leaf disks amended with a preparation of cellulase from Penicillium funiculosum, the digestive fluids of the animals acquired a level of cellulase activity comparable to that present on the leaf disks that were being used as food (Table 4). Animals reared on leaf disks amended with a heat-inactivated cellulase preparation did not acquire elevated levels of cellulase activity. These experiments demonstrate that the acquisition of a cellulolytic capacity by $T$. rathke $i$ is possible if their food contains the requisite enzymes of the cellulase complex. 
Table 4. Enzymatic activity toward microcrystalline cellulose of gut extracts from isopods fed natural leaf litter and black walnut leaf disks amended with Penicillium funiculosum cellulase and of extracts of natural litter and black walnut leaf disks amended with cellulase

\begin{tabular}{ll}
\hline Source of extract & Enzymatic activity \\
& [units per milligram \\
& (dry weight) of \\
dissolved solids & in extract] \\
\hline
\end{tabular}

\section{T. rathkei}

Collected from natural leaf litter

$0.04 \pm 0.02$

(7)

Cultured for 2 weeks on leaf disks plus cellulase (immediately prior to transfer of isopods to dual labeled leaf litter)

Cultured for 2 weeks on leaf disks plus cellulase (four days after transfer of isopods to dual labeled leaf litter)

Cultured for 2 weeks on leaf disks plus heat-inactivated cellulase

$1.40 \pm 0.10$

$0.99 \pm 0.20$

$0.09 \pm 0.02$

Food

Natural leaf litter

$0.10 \pm 0.07$

Leaf disks plus cellulase

$1.31 \pm 0.10$

Leaf disks plus heat-inactivated cellulase

a A unit of activity is the amount of enzyme required to liberate 1 micromole of maltose equivalents per hour under the conditions of the assay $\left(37^{\circ} \mathrm{C}, \mathrm{pH} 5.5\right.$, incubation volume $\left.1.0 \mathrm{ml}\right)$. Each value is the mean \pm standard error of the mean for the number of replicates in parenthesis

Table 5. Assimilation efficiency of $\left[\mathrm{U}-{ }^{14} \mathrm{C}\right]$-wheat straw by Tracheoniscus rathkei

\begin{tabular}{lc}
\hline Diet immediately prior to experiment & $\begin{array}{l}\text { Assimilation } \\
\text { efficiency }\end{array}$ \\
\hline Two weeks on cellulase-amended leaf disks & $24.7 \pm 0.2$ \\
Two weeks on cellulase-free leaf disks & $6.4 \pm 0.1$ \\
\hline
\end{tabular}

* Each value is the mean \pm standard error of the mean for six replicate analyses of the ${ }^{5}{ }^{1} \mathrm{Cr}:{ }^{14} \mathrm{C}$ ratio in the food and fecal material from a single feeding trial. Differences between means are significant, $P \ll 0.05$, T-test

When fed leaf disks labeled with ${ }^{51} \mathrm{CrCl}_{3}$ (an unassimilated marker) and ${ }^{14} \mathrm{C}$-wheat straw, the $T$. rathkei population reared on cellulase-amended leaves assimilated $24 \%$ of the carbon in the labeled wheat straw (Table 5), whereas the isopods reared on cellulase-free leaves assimilated only $6 \%$ of the label. Thus, the efficiency of utilization of plant structural polysaccharides by $T$. rathkei was significantly increased following the ingestion of fungal cellulase.

\section{Discussion}

Ingested microbial enzymes have been shown to play an important role in the digestion of wood by macrotermitine

termites (Abo-Khatwa 1978; Martin and Martin 1978, 1979), siricid woodwasps (Kukor and Martin 1983), and cerambycid beetles (Kukor and Martin 1986). Enzymes originating in microbe-rich substrates have also been reported in a number of detritus-feeders, but to date there has been no compelling demonstration that ingested enzymes make a significant contribution to digestion in any of these species. Our finding that an ingested xylanase is stable and active in the alimentary tract of $T$. rathkei, but that it fails to make a quantitatively significant contribution to fiber digestion, emphasizes the need for caution in assigning an important digestive function to ingested enzymes merely on the basis of evidence that points to their presence in gut fluid. Thus, while it is possible that a $\mathrm{C}_{\mathrm{x}}$-cellulase present in the alimentary tract of larvae of the sciarid fly, Trichosia pubescens, may be an ingested microbial enzyme (Espinoza-Fuentes et al. 1984), there is no reason to presume that it contributes to fiber digestion until it is established that these animals are actually able to digest cellulose. In fact, it is quite unlikely that this enzyme would be active under the highly alkaline conditions which prevail in the midgut of this species. Hassall and Jennings (1975) make a compelling case that a $\mathrm{C}_{\mathrm{x}}$-cellulase in the gut fluid of the terrestrial isopod, Philoscia muscorum, is derived from the food, but in this species also there is no evidence for cellulose digestion, and hence no basis for postulating that this ingested enzyme contributes in any way to digestive processes occurring in the animal. The amphipod, Gammarus fossarum (Bärlocher 1982), and the stonefly, Pteronarcys proteus (Sinsabaugh et al. 1985), are able to digest cellulose, and there is evidence that cellulolytic enzymes present in the gut fluids of both species originate from the food. Thus, a plausible case can be made that acquired enzymes are contributing to cellulose digestion in these species. However, until it is demonstrated experimentally that the efficiency of cellulose or fiber assimilation is higher in individuals with acquired enzymes than in ones lacking them, the evidence for a significant contribution to cellulose digestion by ingested enzymes falls short of being compelling. Taylor (1982) provides convincing evidence that cellulose and hemicellulose digestion in the millipedes, Orthoporus ornatus and Comanchelus sp., are mediated by bacterial enzymes, but it seems likely that these are enzymes secreted by bacteria already in the gut, not enzymes acquired from the food.

For an ingested enzyme to contribute to improved efficiency of food utilization by the organism ingesting it, four conditions must be met: (1) the enzyme must be stable in the gut milieu, (2) the enzyme must be active in the gut milieu, (3) the food must contain a substrate on which the enzyme can act, and (4) the enzyme must be of a type not produced in significant amounts by the ingesting organism or by endosymbionts of the ingesting organism. In the case of the microbial xylanase ingested by $T$. rathkei, the first three conditions are met, but the fourth is not. The ingested xylanase fails to enhance digestive efficiency because it is redundant to enzymes already present in the gut. By contrast, the $T$. rathkei used in this study have very limited cellulolytic capacity. When a microbial cellulase is ingested, all four conditions are met, and the efficiency of fiber digestion is significantly enhanced.

Since the cellulase acquired by $T$. rathkei in this study was not one naturally present in the leaf litter on which the animals normally feed, we cannot claim to have demon- 
strated a significant contribution to digestion by ingested enzymes in a natural population of a detritivore. However, this study is the first direct demonstration that digestive efficiency in a detritivore can be enhanced by the ingestion of microbial enzymes, and certainly emphasizes the potential of acquired enzymes to augment the digestive capabilities of detritus-feeding invertebrates. Future studies in this area must assess the effect of acquired enzymes on digestive efficiency in detritivores, in addition to merely demonstrating their presence.

Acknowledgments. We thank Ron Westman for advice on isopod culturing techniques, and David Hicks and Wayne Frasch for technical assistance. We thank Dr. J.M. Tiedje, Michigan State University, for his generous gift of the $\left[\mathrm{U}-{ }^{14} \mathrm{C}\right]$ wheat straw used in this study. This research was supported by NSF grant PCM-82-03537 to M.M. Martin.

\section{References}

Abo-Khatwa N (1978) Cellulase of fungus growing termites: a new hypothesis on its origin. Experientia 34:559-560

Anderson NH, Sedell JR (1979) Detritus processing by macroinvertebrates in stream ecosystems. Annu Rev Entomol 24:351-377

Baker JH, Bradnam LA (1976) The role of bacteria in the nutrition of aquatic detritivores. Oecologia (Berlin) 24:95-104

Bärlocher F (1982) The contribution of fungal enzymes to the digestion of leaves by Gammarus fossarum Koch (Amphipoda). Oecologia (Berlin) 52:1-4

Bernfeld P (1955) Amylases, $\alpha$ and $\beta$. In: Colowick SP, Kaplan NO (eds) Methods in Enzymology, vol 1. Academic Press, New York, pp 149-150

Berrie AD (1976) Detritus, microorganisms and animals in fresh water. In: Anderson JM, Macfadyen A (eds) The Role of Terrestrial and Aquatic Organisms in Decomposition Processes. Blackwells, Oxford, pp 328-338

Burns RG (ed) (1978) Soil Enzymes. Academic Press, London

Calow P, Fletcher CR (1972) A new radiotracer technique involving ${ }^{14} \mathrm{C}$ and ${ }^{51} \mathrm{Cr}$ for estimating the assimilation efficiencies of aquatic, primary consumers. Oecologia (Berlin) 9:155-170

Cummins KW, Klug MJ (1979) Feeding ecology of stream invertebrates. Annu Rev Ecol Syst 10:147-172

Edney EB, Allen W, McFarlane J (1974) Predation by terrestrial isopods. Ecology 55:428-433

Espinoza-Fuentes FP, Ferreira C, Terra W (1984) Spatial organization of digestion in the larval and imaginal stages of the sciarid fly Trichosia pubescens. Insect Biochem 14:631-638

Findlay S, Meyer JL, Smith PJ (1984) Significance of bacterial biomass in the nutrition of a fresh-water isopod (Lirceus sp.). Oecologia (Berlin) 63:38-42

Hartenstein R (1964) Feeding, digestion, glycogen, and the environmental conditions of the digestive system in Oniscus asellus. J Ins Physiol 10:611-621

Hassall M, Jennings JB (1975) Adaptive features of gut structure and digestive physiology in the terrestrial isopod Philoscia muscorum (Scopoli) 1763. Biol Bull 149:348-364

Herscowitz B, McKillip TW (1974) A simple method for liquid scintillation counting of ${ }^{125}$ Iodine and ${ }^{51}$ Chromium used in antigen binding and cytotoxicity studies. J Immunol Meth 4:253-262

Kelley WA, Adams RP (1977) Preparation of extracts from juniper leaves for electrophoresis. Phytochemistry 16:513-516

Kukor JJ, Martin MM (1983) Acquisition of digestive enzymes by siricid woodwasps from their fungal symbiont. Science 220:1161-1163

Kukor JJ, Martin MM (1986) Cellulose digestion in Monochamus marmorator $\mathrm{Kby}$. (Coleoptera: Cerambycidae): the role of acquired fungal enzymes. J Chem Ecol (in press)

Linkins AE, Atlas RL, Gustin P (1978) Effects of surface applied crude oil on soil and vascular plant root respiration, soil cellulase, and aryl hydrocarbon hydroxlase at Barrow, Alaska. Arctic 31:355-365

Ljungdahl LG, Erikkson K-E (1985) Ecology of microbial cellulose degradation. Adv Microbial Ecol 8:237-299

Martin MM, Kukor JJ (1984) Role of mycophagy and bacteriophagy in invertebrate nutrition. In: Klug MJ, Reddy CA (eds) Current Perspectives in Microbial Ecology. American Society for Microbiology, Washington, D.C., pp 257-263

Martin MM, Martin JS (1978) Cellulose digestion in the midgut of the fungus-growing termite Macrotermes natalensis: the role of acquired digestive enzymes. Science 199:1453-1455

Martin MM, Martin JS (1979) The distribution and origins of the cellulolytic enzymes of the higher termite Macrotermes natalensis. Physiol Zool 52:1-11

Martin MM, Martin JS, Kukor JJ, Merritt RW (1980) The digestion of protein and carbohydrate by the stream detritivore, Tipula abdominalis (Diptera: Tipulidae). Oecologia (Berlin) 46:360-364

Martin MM, Kukor JJ, Martin JS, O'Toole TE, Johnson MW (1981) Digestive enzymes of fungus-feeding beetles. Physiol Zool 54:137-145

Nielsen CO (1962) Carbohydrases in soil and litter invertebrates. Oikos 13:200-215

Nielsen CO (1963) Laminarinases in soil and litter invertebrates. Nature 199:1001

Paris OH (1963) The ecology of Armadillidium vulgare (Isopoda: Oniscoidea) in California grassland: food, enemies, and weather. Ecol Monogr 33:1-22

Piccioni R, Bellemare G, Chua N-H (1982) Methods of polyacrylamide gel electrophoresis in the analysis and preparation of plant polypeptides. In: Edelman M, Hallick RB, Chua N-H (eds) Methods in Chloroplast Molecular Biology. Elsevier, Amsterdam, pp 985-1014

Reyes VG, Tiedje JM (1976a) Ecology of the gut microbiota of Tracheoniscus rathkei (Crustacea, Isopoda). Pedobiologia 16:67-74

Reyes VG, Tiedje JM (1976b) Metabolism of ${ }^{14} \mathrm{C}$-labeled plant materials by woodlice (Tracheoniscus rathkei Brandt) and soil microorganisms. Soil Biol Biochem 8:103-108

Shachak M, Chapman EA, Steinberger Y (1976) Feeding, energy flow and soil turnover in the desert isopod, Hemilepistus reaumuri. Oecologia (Berlin) 24:57-69

Sinsabaugh RL, Benfield EF, Linkins AE (1981) Cellulase activity associated with the decomposition of leaf litter in a woodland stream. Oikos 36:184-190

Sinsabaugh RL, Linkins AE, Benfield EF (1985) Cellulose digestion and assimilation by three leaf shredding aquatic insects. Ecology 66:1464-1471

Swift MJ, Heal OW, Anderson JM (1979) Decomposition in Terrestrial Ecosystems. University of California Press, Berkeley

Taylor EC (1982) Role of aerobic microbial populations in cellulose digestion by desert millipedes. Appl Environ Microbiol 44:281-291

White JJ (1968) Bioenergetics of the woodlouse Tracheoniscus rathkei Brandt in relation to litter decomposition in a deciduous forest. Ecology 49:694-704

Received December 3, 1985 